\title{
Entrepreneurial Competencies and Higher Education Institutions: A bibliometric study
}

\author{
Carmen Florina FAGADAR ${ }^{1}$, Diana Teodora TRIP ${ }^{2}$ \\ And Daniel BADULESCU ${ }^{3}$ \\ ${ }^{1,2}$ Doctoral School of Economics, Faculty of Economic Sciences, University of Oradea, Romania \\ ${ }^{3}$ Department of Economics and Business \& Doctoral School of Economics, Faculty of Economic \\ Sciences, University of Oradea
}

Correspondence should be addressed to: Diana Teodora TRIP; dianateodora.trip@gmail.com

Received date:17 March 2021; Accepted date:16 June 2021; Published date: 29 July 2021

Academic Editor: Cezar Scarlat

Copyright (C) 2021. Carmen Florina FAGADAR, Diana Teodora TRIP and Daniel BADULESCU. Distributed under Creative Commons Attribution 4.0 International CC-BY 4.0

\begin{abstract}
Conventional wisdom in entrepreneurship education holds that educational institutions play a key influence in developing entrepreneurial capabilities. However, the buzzing, complex debates about entrepreneurship, as well as the varied signals from the market about the real outcome of such transformational undertakings, pave the way for additional in-depth research. The developing literature has a plethora of nuances and subtleties to source, ranging from the formulation of complex, multilayered concepts to the evaluation of longitudinal studies. This study aims to generate new bibliometric insights and establish an agenda for further study into key and relevant subjects. In doing so, the state of the art of this dual study field is mapped out, and pertinent emerging patterns are summarized. Bibliometric methods were used for the mapping of the knowledge base, utilizing HistCite and VosViewer. Following the interrogation of the Web of Science platform, a meaningful sample of peer-reviewed papers were yielded for which bibliometric analyses were conducted. The findings show that this topic is divided into three interconnected clusters that provide a clearer understanding of the various research streams that run through it, as well as the gaps and future research trends.
\end{abstract}

Keywords: Entrepreneurship Education; entrepreneurial competencies; higher education institutions; HEI; bibliometrics.

Cite this Article as: Carmen Florina FAGADAR, Diana Teodora TRIP and Daniel BADULESCU (2021),"Entrepreneurial Competencies and Higher Education Institutions: A bibliometric study ", Journal of e-Learning and Higher Education, Vol. 2021 (2021), Article ID 804268, DOI: 10.5171/2021.804268 


\section{Introduction}

For a significant time, the concept of entrepreneurship education (EE) encapsulated the force of opportunities and responsibilities for change and development, growth and socio-economic wellbeing, from both perspectives, the educators' and the industry's. The consensus on the symbiotic relationship between entrepreneurial initiative and the higher education institutions (HEI) did not translate fully into all intricacies of what EE implies. One area that needs further investigation is the area of entrepreneurial competencies - how are such competencies formed, and to what degrees are they determined by the learning ecosystems and specifically, by the academic institutions of nowadays? In the sprint to offer students greater employability currency, what significance is it offered to the entrepreneurial option? What are the right competencies for entrepreneurial initiative, and how are they best formed?

The conversation is diverse, the lines of inquiry are numerous. However, a balanced discussion must be built upon existing research. Gaps must be identified and followed up. Research trends need to be acknowledged and evaluated for impact potential. This paper intends to map out the research on entrepreneurial competencies in relationship with HEI and identify relevant lines of study for future research.

\section{Current streams of research in the relevant literature}

There is a relatively large theoretical and practical consensus that people who launch and develop a business already possess certain entrepreneurial skills (Mitchelmore \& Rowley, 2010), proven by organizing resources and capitalizing on opportunities (Bird, 1995). Equally widespread, however, is the idea that the vital importance of entrepreneurship in the modern economy and society cannot be left to these "spontaneous encounters" of individual entrepreneurial skills, so the entrepreneurial education of young generations, especially students, is critical. Several reports of Global Entrepreneurship Monitor (GEM) claim that "strong correlation between perceived capabilities and total early entrepreneurial activity (TEA) indicates that all forms of education (formal, informal, non-formal) are important in developing entrepreneurial competencies" (Global Entrepreneurship Monitor, 2014, p. 38).

The modern entrepreneurship education's dilemma is not only about the difficulty to teach students all the skills that would ensure their successful future activity in the entrepreneurial field, but also if this could be possible, as the pedagogical competencies and entrepreneurship education methods are still being developed (Matlay, 2008), (Baptista \& Naia, 2015), (Maresch, et al., 2016).

According to Man et al (2002), entrepreneurial skills can be defined as a set of specific characteristics expressed by entrepreneurs' capacities to succeed in the proposed project. Here can be listed employability, personal initiative, selflearning, and business development. Chandler \& Jansen (1992) consider that there are three main groups of skills needed for entrepreneurial success: managerial skills, technical (or functional) skills, and entrepreneurial skills. In other words, entrepreneurial skills (although very important) are not enough for the success of the business, and they are better valued at the launch and fast growth of the business (Sánchez, 2011). On the other hand, managerial or technical skills are more about managing an established business, taking into account the multitude of expectations coming from shareholders or stakeholders. Other researchers refer to five large groups of entrepreneurial competencies that can be taught and learned: (1) recognizing the business opportunity, (2) develop an entrepreneurial vision: from the opportunity to the project, (3) designing the business model, (4) rendering them into a business plan, and (5) 
boost an organization: from the project to the structure (Loué, et al., 2008), (FerrerasGarcia, et al., 2019). There is no clear consensus on exact limits of the taxonomy of entrepreneurial competence. Tittel and Terzidis (2020) identified five approaches encompassing 14 distinct categories of competences, gathered from sources such as policy makers (European Union, US National research Council, national qualification networks) and competence assessment handbooks. The definitions differ in terms of the degree of inclusiveness, competence being defined as a combination of knowledge, skills, abilities, cognitive dispositions, capacities, and other personal characteristics. Competence is finally condensed by Tittel and Terzidis (2020) in three main categories: personal competence, social competence, and domain competence.

According to Smith et al. (2010), Higher Education Institutions (HEI) should be "more pro-active in providing postgraduates with the opportunity to develop the core competencies they need to succeed in a competitive job market" (Smith, et al., 2010, p. 5). From this point of view, it is essential that teachers, all those involved in career guidance and entrepreneurship education, be well trained, with practical and theoretical skills to effectively manage a continuous training process (CEDEFOP (European Centre for the Development of Vocational Training), 2005). Thus, the teaching of entrepreneurship must give students those essential skills to start a business (Kakkonen, 2011) and help them develop the knowledge necessary for its management, both during their studies and later, running daily businesses (Politis, 2005), to facilitate the continuous accumulation of entrepreneurial competencies (Sánchez, 2011), (FerrerasGarcia, et al., 2019).

Badulescu et al (2020) consider that there is a need for an interdisciplinary approach to entrepreneurship education to correctly direct students to understand the real issues of setting up and running a business. HEIs have to create opportunities for students to work beyond the core economic qualification and be part of teams with various abilities and competencies. In this regard, teachers must encourage and stimulate students' knowledge outside the classroom - by taking part in training sessions, business plan competitions, interacting with entrepreneurs and experts in the business field, and develop networks (Badulescu, et al., 2020). Ferreras-Garcia et al (2019) consider that already "classic" techniques, such as student involvement in creating and analyzing a business plan, could generate highly rated entrepreneurial competence; "whether the business plan is real or fictitious, does not affect the level of entrepreneurial competence" (FerrerasGarcia, et al., 2019, p. 850).

However, Fatoki (2010) advises many competencies and skills developed by graduates in HEIs are unsuitable for the business world requirements and recommends an entrepreneurial education accessible to all students and postgraduates, emphasizing creativity, innovation, risk-taking, and the ability to interpret successful entrepreneurial models and identify opportunities. Authentic internships and tangible experiences in active businesses, from the real economy, for at least one year, are essential (Fatoki, 2010). HEIs must recognize and introduce these valuable technical, organizational, and business experiences in the entrepreneurial university program to increase the share of graduates successfully involved in entrepreneurial activities (Badulescu \& Badulescu, 2013). "When learners are oriented into entrepreneurship from an early age, it becomes easier to develop successful ventures" (Fatoki, 2010, p. 93).

\section{Research Methodology}

In order to map out the state of the art in entrepreneurship education with a focus on entrepreneurial competencies and HEIs, the following research questions were proposed:

RQ1 - What authors, articles, journals, countries, and institutions are leading the way with relevant research? 
RQ2 - What research themes have been studied most, and what research streams are likely to be developed in the future?

The methodology employed is the bibliometric analysis, a method that gathered momentum in the last years, capitalizing on a handful of specialized tools and on the development of research databases and platforms such as Scopus and Web of Science. The bibliometric method is based on statistical analyses of published articles and the citations they contain in order to measure their impact. It is also helpful for quantifying research output, identifying cooperation patterns between research and performance of articles, authors, journals, and for assessing interdisciplinarity of research (Waltman \& Noyons, 2018). For the present study, the HistCite software was used, which pinpoints the most cited articles and indicates the ensuing impact of those citations (Thelwall, 2008), and VosViewer software for studying and visualizing clusters of research themes based on keyword co-occurrence analysis.
Figure 1 illustrates the research methodology used in this study. Data is collected from the Web of Science Core Collection, a database used by many other similar studies (Fetscherin \& Heinrich, 2015). The WOS Core Collection covers more than 21,400 journals, books, and conference proceedings with over 79 million records (as of March 2021, from clarivate.libguides.com). The search technique included a Boolean search using a combination of the keywords: entrepreneur* competenc* or abilit* or skill* and higher education or HEI. Although the use of the key-words competence, ability, and skill in an interchangeable manner is debatable, this study allowed for the grouping of all these terms in the query, in order to capture any fringing research done on this theme. In this way, a larger view of the term entrepreneurial competencies, as presented in the title of this paper, has been assumed.

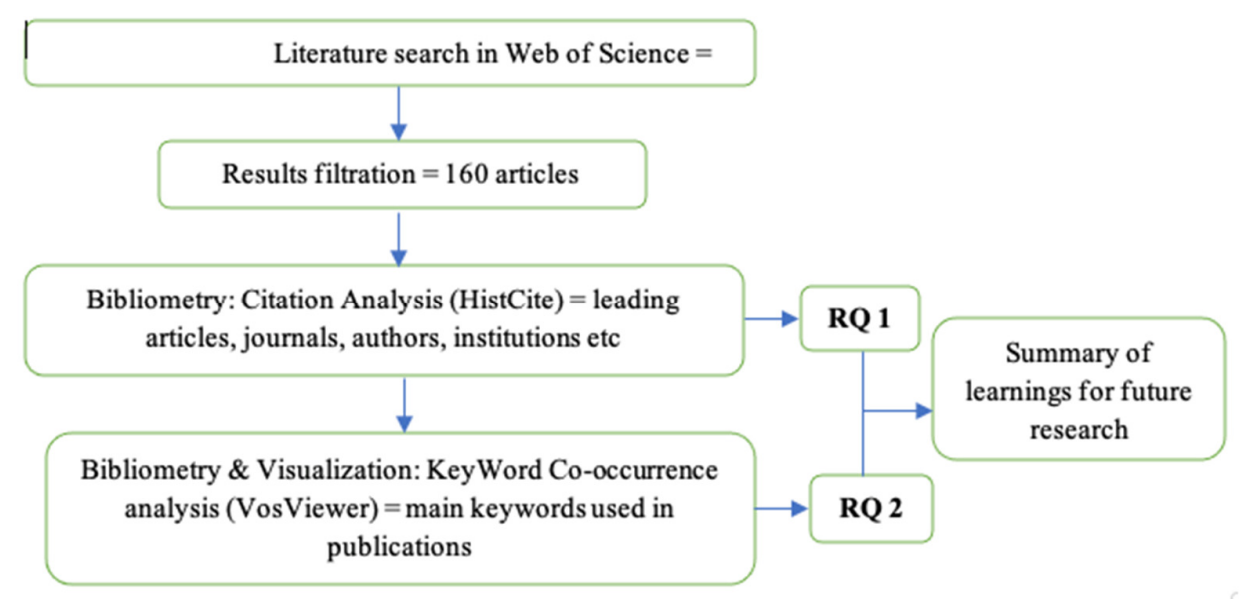

Source: produced by authors

Fig. 1: Research methodology

The search obtained a collection of 763 records which were then filtered by language (English), WOS categories (education, educational research, business, management, economics), and document types (articles), resulting in 160 articles suited for our study. The time span of the search was all years.
For the 160 articles, the following were extracted: the article title, author name(s) and affiliation, journal name, number, volume, pages, date of publication, abstract, and cited references. Then the bibliometric analysis was conducted, employing the two specialized software - HistCite, and VosViewer. 
The mapping of the research proposed herein is therefore obtained by grouping the findings of RQ1 and RQ2, then summarizing the learnings.

\section{Results and Discussions}

Answering the first research question of this study needed a thorough analysis of the article collection, both for obtaining an image of the scientific output evolution in time and for ranking research and researchers in terms of impact (authors, articles, journals, countries, and institutions having leading positions).

\section{Yearly Output Evolution}

Research activity was measured by the number of publications during our study period. As HistCite results reveal, the first article related to these topics was published in 2005 in the Journal of Engineering Education, entitled Developing and assessing students' entrepreneurial skills and mind-set (Bilen et. al, 2005). Figure 2 displays the results in terms of yearly output evolution. The year with the most results was 2020, with 37 papers. So far, the year 2021 is credited with five articles in this count. Interestingly, there are no studies identified for the period 2007 to 2008 . Yet, noticeably, the last five years (2016 - 2021) represent about 80 percent of the total articles published since 2005. This indicates that the research field attracted in the later years more and more attention from both the scientific community and practitioners.

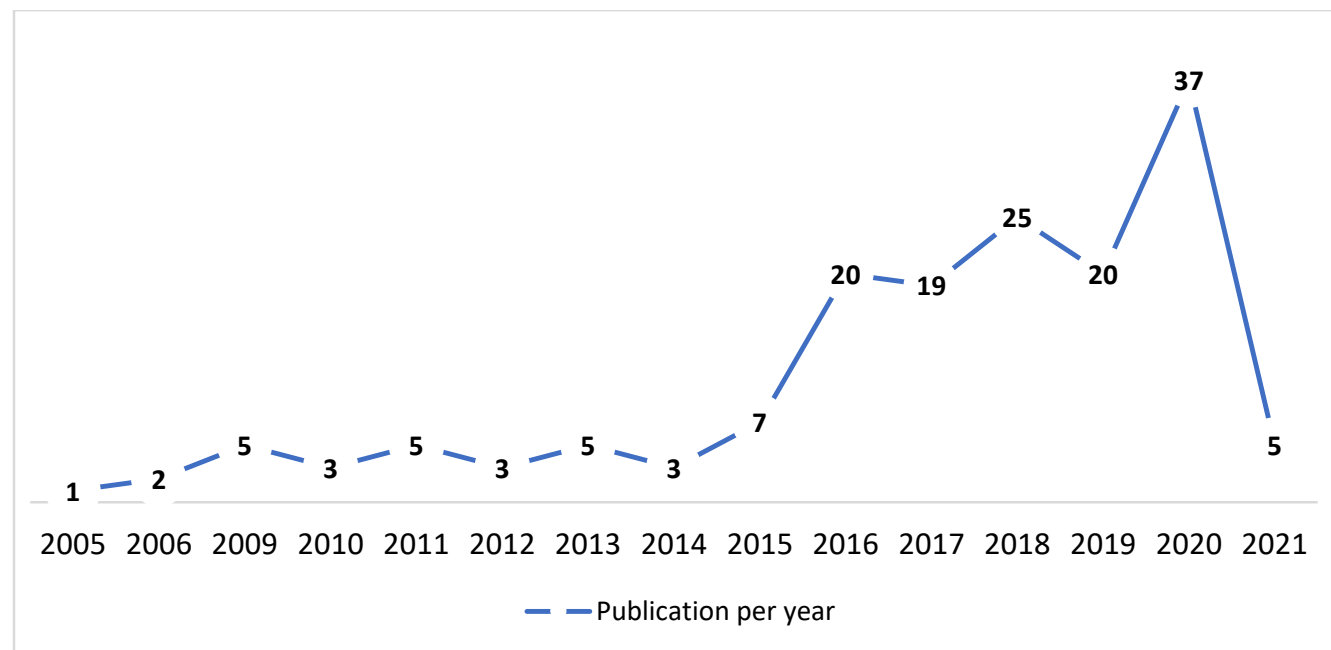

Fig. 2: Yearly evolution of scientific output (publications per year)

Source: retrieved from HistCite

Leading authors, articles, journals, countries and institutions

Many authors had important contributions to the development of the entrepreneurship education research field, specifically studying the entrepreneurial competencies in connection to higher education institutions. The section presents some of these authors, based on the data found in WoS and ranked using HistCite. The results indicate that 428 authors contributed to the publication of 160 articles in 98 journals.
The author with the highest number of articles is Rasmussen, with five papers published between 2014 and 2017. Table 1 shows the first ten authors ranked on the number of articles, representing 20 percent of the total articles found in WoS using the search terms. Even if the evolution of scientific production presented in Figure 1 revealed the field is continuously growing, the fact that only a few authors published more than four articles exhibits a low concentration of study on this field. 
Table 1: Most productive authors from 160 publications - Publications ranking

\begin{tabular}{|l|l|l|}
\hline No. & Authors & $\begin{array}{l}\text { Publicatio } \\
\text { ns }\end{array}$ \\
\hline $\mathbf{1}$ & Rasmussen, E. & 5 \\
\hline $\mathbf{2}$ & Wright, M. & 5 \\
\hline $\mathbf{3}$ & Mosey, S. & 4 \\
\hline $\mathbf{4}$ & Ferreras-Garcia, R. & 3 \\
\hline $\mathbf{5}$ & Kucel, A. & 3 \\
\hline $\mathbf{6}$ & Serradell-Lopez, E. & 3 \\
\hline $\mathbf{7}$ & Badawi, S. & 2 \\
\hline $\mathbf{8}$ & Bejinaru, R. & 2 \\
\hline $\mathbf{9}$ & Belas, J. & 2 \\
\hline $\mathbf{1 0}$ & Bell, H. & 2 \\
\hline
\end{tabular}

Source: retrieved from HistCite

In order to determine the most-cited authors, first, the 428 authors were ranked using TLCS (Total Local Citation Score). TLCS points how many citations an article has within the collection of the retrieved set. Besides being the most productive author, Rasmussen is also one of the most cited authors with a TLCS score of 22 . Wright and
Mosey were among the most productive authors, and they are ranked in the first three places in the list of most influential authors according to TLCS score (Table 2). It is necessary to note the TLCS score of 11 obtained by Sanchez with just one article published on this topic.

Table 2: Most influential authors from 160 entrepreneurial publications - TLCS ranking

\begin{tabular}{|l|l|l|l|}
\hline No. & Authors & $\begin{array}{l}\text { Publicatio } \\
\text { ns }\end{array}$ & TLCS \\
\hline $\mathbf{1}$ & Rasmussen, E. & 5 & 22 \\
\hline $\mathbf{2}$ & Wright, M. & 5 & 22 \\
\hline $\mathbf{3}$ & Mosey, S. & 4 & 19 \\
\hline $\mathbf{4}$ & Sanchez, JC. & 1 & 11 \\
\hline $\mathbf{5}$ & Binks, M. & 1 & 4 \\
\hline $\mathbf{6}$ & Kassean, H. & 1 & 4 \\
\hline $\mathbf{7}$ & Kucel, A. & 3 & 4 \\
\hline $\mathbf{8}$ & Liguori, E. & 1 & 4 \\
\hline $\mathbf{9}$ & Mahon, CL. & 1 & 4 \\
\hline $\mathbf{1 0}$ & Starkey, K. & 1 & 4 \\
\hline
\end{tabular}

Source: retrieved from HistCite

The next step was to list the authors according to TGCS (Total Global Citation Score), a bibliometric criterion that measures how many times an article was cited not only in the core collection, but globally. Based on the analysis, Rasmussen and Wright have the highest TGCS score, obtained from the same publications. Kassean, Liguori, Vanevenhoven, Winkel obtained a TGCS score of 95 from the authors' collaboration in one article, 
followed by Miller and Wesley, also with one article.

Table 3: Most influential authors from 160 entrepreneurial publications - TGCS ranking

Source: retrieved from HistCite

\begin{tabular}{|l|l|l|l|}
\hline No. & Authors & $\begin{array}{l}\text { Publicatio } \\
\text { ns }\end{array}$ & TGCS \\
\hline $\mathbf{1}$ & Rasmussen, E. & 5 & 511 \\
\hline $\mathbf{2}$ & Wright, M. & 5 & 511 \\
\hline $\mathbf{3}$ & Mosey, S. & 4 & 372 \\
\hline $\mathbf{4}$ & Sanchez, JC. & 1 & 148 \\
\hline $\mathbf{5}$ & Kassean, H. & 1 & 95 \\
\hline $\mathbf{6}$ & Liguori, E. & 1 & 95 \\
\hline $\mathbf{7}$ & Vanevenhoven, J. & 1 & 95 \\
\hline $\mathbf{8}$ & Winkel, DE. & 1 & 95 \\
\hline $\mathbf{9}$ & Miller, TL. & 1 & 79 \\
\hline $\mathbf{1 0}$ & Wesley, CL. & 1 & 79 \\
\hline
\end{tabular}

Table 4 shows the most cited ten articles sorted by TGCS score. Here again, Rasmussen took the first place, with a TGCS of 207, as coauthor with Mosey and Wright, who published the most cited article in Journal of Management Studies in 2011.
Rasmussen attracted the attention of academic researchers with another three articles, receiving a TGCS score of 110,86 and 55. The ten most influential articles were published between 2009 and 2017.

Table 4: Papers with the highest number of citations

\begin{tabular}{|c|c|c|c|c|c|}
\hline No & Title & Year & Authors & Journal & TGCS \\
\hline 1 & $\begin{array}{l}\text { The Evolution of } \\
\text { Entrepreneurial Competencies: } \\
\text { A Longitudinal study of } \\
\text { University Spin-Off Venture } \\
\text { Emergence }\end{array}$ & $\begin{array}{c}201 \\
1\end{array}$ & $\begin{array}{l}\text { Rasmussen, E., } \\
\text { Mosey S., } \\
\text { Wright, M. }\end{array}$ & $\begin{array}{l}\text { Journal of } \\
\text { Management Studies }\end{array}$ & 207 \\
\hline 2 & $\begin{array}{l}\text { University training for } \\
\text { entrepreneurial competencies: } \\
\text { It's Impact on Intentions of } \\
\text { Venture Creation }\end{array}$ & $\begin{array}{c}201 \\
1\end{array}$ & Sanchez, J.C. & $\begin{array}{l}\text { International } \\
\text { Entrepreneurship } \\
\text { and Management } \\
\text { Journal }\end{array}$ & 148 \\
\hline 3 & $\begin{array}{l}\text { The Influence of University } \\
\text { Departments on the Evolution } \\
\text { of Entrepreneurial } \\
\text { Competencies in Spin-off } \\
\text { Ventures }\end{array}$ & $\begin{array}{c}201 \\
4\end{array}$ & $\begin{array}{c}\text { Rasmussen, E., } \\
\text { Mosey S., } \\
\text { Wright, M. }\end{array}$ & Research Policy & 110 \\
\hline 4 & $\begin{array}{l}\text { Entrepreneurship Education: a } \\
\text { Need for Reflection, Real-world } \\
\text { Experience and Actions }\end{array}$ & $\begin{array}{c}201 \\
5\end{array}$ & $\begin{array}{l}\text { Kassean, H., } \\
\text { Vanevenhoven } \\
\text {, J., Liguori, E., } \\
\text { Winkel, D.E. }\end{array}$ & $\begin{array}{l}\text { International } \\
\text { Journal of } \\
\text { Entrepreneurial } \\
\text { Behavior\&Research }\end{array}$ & 95 \\
\hline 5 & $\begin{array}{l}\text { How can Universities Facilitate } \\
\text { Academic Spin-offs? An } \\
\text { Entrepreneurial Competency } \\
\text { Perspective }\end{array}$ & $\begin{array}{c}201 \\
5\end{array}$ & $\begin{array}{l}\text { Rasmussen, E., } \\
\text { Wright, M. }\end{array}$ & $\begin{array}{l}\text { Journal of } \\
\text { Technology Transfer }\end{array}$ & 86 \\
\hline
\end{tabular}

Carmen Florina FAGADAR, Diana Teodora TRIP and Daniel BADULESCU, Journal of e-Learning and Higher Education, DOI: 10.5171/2021.804268 


\begin{tabular}{|c|c|c|c|c|c|}
\hline 6 & $\begin{array}{l}\text { Educating the Minds of Caring } \\
\text { Hearts: Comparing the Views of } \\
\text { Practitioners and Educators on } \\
\text { the Importance of Social } \\
\text { Entrepreneurship } \\
\text { Competencies }\end{array}$ & $\begin{array}{c}201 \\
2\end{array}$ & $\begin{array}{c}\text { Miller, T.L., } \\
\text { Wesley, C.L, } \\
\text { Williams, D.E. }\end{array}$ & $\begin{array}{l}\text { Academy of } \\
\text { Management } \\
\text { Learning\&Education }\end{array}$ & 79 \\
\hline 7 & $\begin{array}{l}\text { The 'Teachability Dilemma' of } \\
\text { Entrepreneurship }\end{array}$ & $\begin{array}{c}201 \\
1\end{array}$ & $\begin{array}{c}\text { Haase, H., } \\
\text { Lautenschlage } \\
\text { r, A. }\end{array}$ & $\begin{array}{l}\text { International } \\
\text { Entrepreneurship } \\
\text { and Management } \\
\text { Journal }\end{array}$ & 73 \\
\hline 8 & $\begin{array}{l}\text { Soft Skills at the Malaysian } \\
\text { Institutes of Higher Learning }\end{array}$ & $\begin{array}{c}200 \\
9\end{array}$ & Shakir, R. & $\begin{array}{l}\text { Asia Pacific } \\
\text { Education Review }\end{array}$ & 65 \\
\hline 9 & $\begin{array}{l}\text { Entrepreneurship Education } \\
\text { and the Business School }\end{array}$ & $\begin{array}{c}200 \\
6\end{array}$ & $\begin{array}{c}\text { Binks, M., } \\
\text { Starkey, K., } \\
\text { Mahon, C.L. }\end{array}$ & $\begin{array}{l}\text { Technology } \\
\text { Analysis\&Strategic } \\
\text { Management }\end{array}$ & 61 \\
\hline 10 & $\begin{array}{l}\text { Institutional Determinants of } \\
\text { the University Spin-off } \\
\text { Quantity and Quality: A } \\
\text { Longitudinal, Multilevel, Cross- } \\
\text { Country Study }\end{array}$ & $\begin{array}{c}201 \\
7\end{array}$ & $\begin{array}{c}\text { Fini, R., Fu, K., } \\
\text { Mathisen, M.T., } \\
\text { Rasmussen, E., } \\
\text { Wright, M. }\end{array}$ & $\begin{array}{l}\text { Small Business } \\
\text { Economics }\end{array}$ & 55 \\
\hline
\end{tabular}

Source: retrieved from HistCite

The stateliest HistCite feature is the visualization of the information flows in a domain (Garfield et al., 2006). There can be identified two types of documents: 'hub' documents, namely documents citing many other documents in the domain and 'authority' documents, which are documents that are being cited by many other documents on the domain (Kleinberg, 1999). The Historiograph (Figure 3) revealed all the documents which were cited globally at least twelve times. There are 30 articles (nodes) and 19 links (relationship among publications) as the most cited. Hub documents of the entrepreneurial competencies and HEI research are Gümüsay and Bohné, 2018, Individual and Organizational Inhibitors to the Development of Entrepreneurial Competencies in Universities (no. 94); RezaeiZadeh, 2017, Core entrepreneurial competencies and their interdependencies: insights from a study of Irish and Iranian entrepreneurs, university students and academics (no. 77); Fini, Fu, Mathisen and Rasmussen, 2017, Institutional Determinants of the University Spin-off
Quantity and Quality: A Longitudinal, Multilevel, Cross-Country Study (no. 76); Rasmussen, Mosey and Wright, 2015, The Transformation on network ties to develop entrepreneurial competencies for university spin-offs (no. 40) and Rasmussen and Wright, 2015, How can Universities Facilitate Academic Spin-offs? An Entrepreneurial Competency Perspective (no. 41). Authority documents are Rasmussen, 2011, The Evolution of Entrepreneurial Competencies: A Longitudinal study of University Spin-Off Venture Emergence (no. 24), Sanchez, 2011, University training for entrepreneurial competencies: It's Impact on Intentions of Venture Creation (no. 23) and Rasmussen, E., Mosey S., Wright, M., 2014, The Influence of University Departments on the Evolution of Entrepreneurial Competencies in Spin-off Ventures. An important aspect to consider in using the Historiograph is the possibility of finding the papers that not necessarily highly cited, but play a significant role in the development of the domain Garfield et al., 2006). 


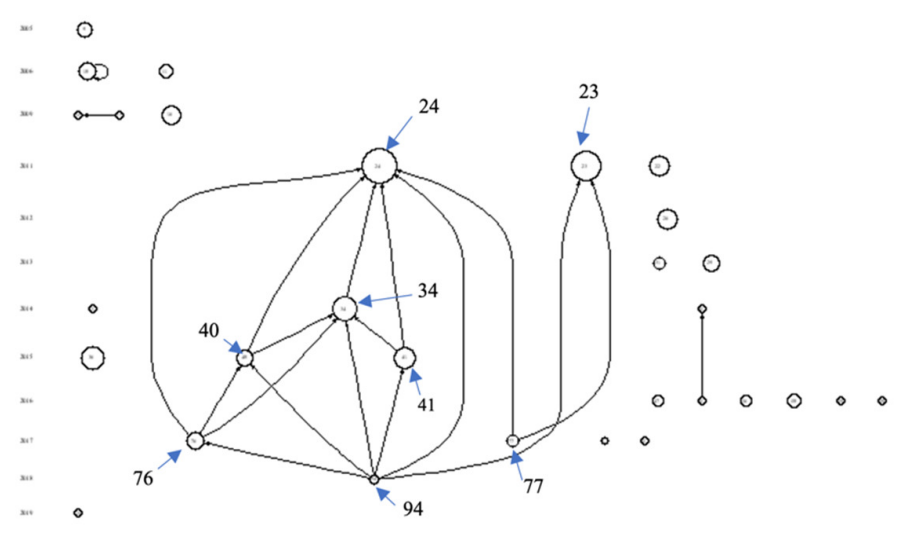

Fig. 3: The Historiograph - co-citation analysis (Global Citation Score) Source: retrieved from HistCite

Regarding the impact of journals, Table 5 shows the journals with the highest number of published articles on the topic analyzed by this study. The most important is
Education and Training, with 16 articles and the results highlight that almost 32 percent of articles published by the top-ten journals were published by this leading journal.

Table 5: Ranking the most productive journals in the field

\begin{tabular}{|l|l|l|}
\hline No. & Journals & Publications \\
\hline $\mathbf{1}$ & Education and Training & 16 \\
\hline $\mathbf{2}$ & $\begin{array}{l}\text { International Journal of Entrepreneurial } \\
\text { Behavior \& Research }\end{array}$ & 5 \\
\hline $\mathbf{3}$ & $\begin{array}{l}\text { Higher Education Skills and Work- } \\
\text { based Learning }\end{array}$ & 4 \\
\hline $\mathbf{4}$ & Industry and Higher Education & 4 \\
\hline $\mathbf{5}$ & $\begin{array}{l}\text { International Entrepreneurship and } \\
\text { Management Journal }\end{array}$ & 4 \\
\hline $\mathbf{6}$ & Journal of Education for Business & 4 \\
\hline $\mathbf{7}$ & Journal of Technology Transfer & 4 \\
\hline $\mathbf{8}$ & Administrative Sciences & 3 \\
\hline $\mathbf{9}$ & $\begin{array}{l}\text { Entrepreneurship and Sustainability } \\
\text { Issues }\end{array}$ & 3 \\
\hline $\mathbf{1 0}$ & $\begin{array}{l}\text { Eurasia Journal of Mathematics Science } \\
\text { and Technology Education }\end{array}$ & 3 \\
\hline
\end{tabular}

Source: retrieved from HistCite

Carmen Florina FAGADAR, Diana Teodora TRIP and Daniel BADULESCU, Journal of e-Learning and Higher Education, DOI: 10.5171/2021.804268 
As regarding the research contribution by country, table 6 indicates the first ten countries with the highest number of publications according to the country where is located the institution with which the authors are affiliated. The contributions of these ten countries represent 72 percent of the documents published in this research field, from a total of 52 countries that have published at least one article related to the topic.

Table 6: Countries with the highest number of articles

\begin{tabular}{|l|l|l|}
\hline No. & Country & Publications \\
\hline $\mathbf{1}$ & UK & 27 \\
\hline $\mathbf{2}$ & Spain & 25 \\
\hline $\mathbf{3}$ & USA & 14 \\
\hline $\mathbf{4}$ & Portugal & 8 \\
\hline $\mathbf{5}$ & Finland & 7 \\
\hline $\mathbf{6}$ & Iran & 7 \\
\hline $\mathbf{7}$ & Malaysia & 7 \\
\hline $\mathbf{8}$ & China & 7 \\
\hline $\mathbf{9}$ & Nigeria & 6 \\
\hline $\mathbf{1 0}$ & Norway & 6 \\
\hline
\end{tabular}

Source: retrieved from HistCite

Furthermore, this study also analyzed active universities or institutions in publishing documents in entrepreneurial competencies and HEI literature, found 250 institutions and ranked them using publication number criteria. The results indicated that Ghent University and University of Nottingham are the most significant institutions, each of them with five publications. Raspussen, who is the most prominent researcher in the collection ranked by number of articles, is responsible for four articles affiliated with Ghent University (Belgium), two of them together with Mosey and Wright, one article with Wright and one in coauthorship with Fini, $\mathrm{Fu}$, Mathisen, and Wright. Two of the publications in coauthor status with Mosey and Wright are also affiliated with University of Nottingham (England). A document with two authors having different institution or country affiliation, without considering if they are main or corresponding authors, is counted for each one, and this has increased the research activity for institutions or countries with significant international research collaboration (Shah et al., 2019). The other eight institutions are Tecnol Monterrey (4 publications), University of Barcelona Spain (4 publications), Imperial College of Science, Technology and Medicine England (4 publications), Nord University Norway (3 publications), Universitat Oberta de Catalunya Spain (3 publications), Universitat Politecnica de Valencia Spain (3 publications), Pompeu Fabra University Spain (3 publications), and University of Teheran (3 publications).

After identifying the staple research done on entrepreneurial competencies and HEI, the main authors, journals, countries, and institutions doing the research, the analysis focused on the themes permeating this research (RQ2). For this, VosViewer and the analysis of keywords based on their cooccurrence in the article set were used. The software extracts the terms most used in the article set (from publication's title, keywords, and abstract) and with the highest relevance score and presents them in a visual form, as seen in figure 4 . VosViewer applies an algorithmic analysis (including the criteria of co-occurrence and link-strength) in order to cluster the terms and provide insights into the research themes of the collection. 


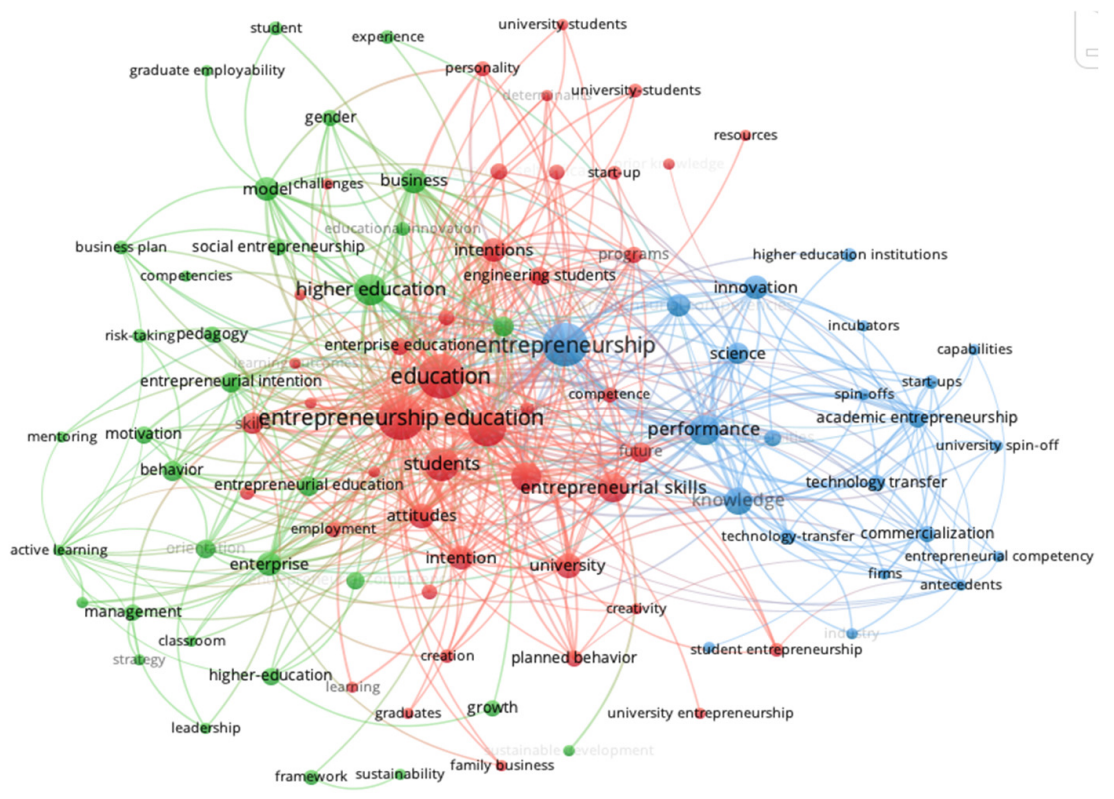

Fig. 4. Keywords' co-occurrence network in the "overlay visualization" display mode Source: retrieved from VosViewer

The analysis provided us with three clusters encompassing relevant research: the red, green, and blue clusters, totalizing 98 keywords, 1338 links, and a total link strength of 2207. As a rule, the size of the circles and of the labels shows the higher number of keyword co-occurrences, the thickness of lines represents the strength of the co-citation links. The functionalities of the software allowed for further exploration of the clusters and for easier identification of research gaps and trends in the field (see Table 7).

\section{Table 7: The clusters - data and insights}

\begin{tabular}{|l|l|l|l|l|}
\hline $\begin{array}{c}\text { Cluster } \\
\text { color }\end{array}$ & \multicolumn{1}{|c|}{$\begin{array}{c}\text { Cluster } \\
\text { name }\end{array}$} & $\begin{array}{l}\text { No. of } \\
\text { items }\end{array}$ & \multicolumn{2}{|c|}{$\begin{array}{c}\text { Summary of learnings for future research } \\
\text { Gaps. }\end{array}$} \\
\hline 1.RED & $\begin{array}{l}\text { Entrepreneursh } \\
\text { ip Education }\end{array}$ & 43 & $\begin{array}{l}\text { Learning outcomes, } \\
\text { models, personality, } \\
\text { perceptions, }\end{array}$ & $\begin{array}{l}\text { Student } \\
\text { entrepreneurship } \\
\text { Planned behaviour, } \\
\text { Creativity, }\end{array}$ \\
\hline 2.GREEN & $\begin{array}{l}\text { Higher } \\
\text { education }\end{array}$ & 33 & $\begin{array}{l}\text { Growth, sustainable } \\
\text { development, } \\
\text { educational } \\
\text { innovation }\end{array}$ & $\begin{array}{l}\text { Frameworks, Graduate } \\
\text { employability, } \\
\text { Sustainability, }\end{array}$ \\
\hline 3.BLUE & $\begin{array}{l}\text { Entrepreneursh } \\
\text { ip }\end{array}$ & 22 & $\begin{array}{l}\text { Science parks, } \\
\text { Technology transfer }\end{array}$ & $\begin{array}{l}\text { Incubators, } \\
\text { Performance, Spin-offs }\end{array}$ \\
\hline
\end{tabular}

Source: produced by authors with data retrieved from VosViewer

The clusters are named after the term with most occurrences. Gaps are identified by exploring the direct and indirect links between terms. All terms in a cluster are connected among themselves through direct links. The connections with other 
terms from other clusters are the indirect links. The circles' sizes, as stated before, show the number of co-occurrences of the keyword. Thus, any relationship between keywords that are highly unbalanced points toward a research gap. Trends are easier identifiable from the same map but in the overlay visualization, which includes the time parameter. In this way, the themes that have caught researchers' attention in a more recent time frame were easier noticeable.

\section{Implications and Conclusions}

In this study, a bibliometric analysis of research on entrepreneurial competencies in relation to HEIs was conducted, analyzing 160 articles identified from the ISI Web of Science database. With the help of bibliometric analysis tools and techniques, leading countries, key journals, productive authors, and impactful articles were identified. The yearly research output displayed a positive, growing trend with the peak of productivity in the year 2020 . Rasmussen and Wright are the most productive authors according to both ranking criteria (TLCS and TGCS), while the most cited work is an article published in 2011 by Rasmussen, Mosey and Wright in the journal Journal of Management Studies, the article entitled The Evolution of Entrepreneurial Competencies: A Longitudinal study of University Spin-Off Venture Emergence. However, the most influential journal in terms of productivity score is Education and Training, with a solid share of 32 percent in the total research production of the top-ten journals. The UK and Spain yielded the first two positions, at a close score, in the ranking of leading countries publishing relevant research. By using HistCite visualization capability, this study highlights the core works, those documents that are being highly cited and the ones that are citing many other documents in the domain. HistCite Historiograph exhibited Rasmussen's work, The Evolution of Entrepreneurial Competencies: A Longitudinal study of University Spin-Off Venture Emergence as iconic for the research of entrepreneurial competencies and HEI. These data can be useful for academics in interdisciplinary studies.

The insights gathered from exploring clusters of research themes grouped through an analysis of keyword cooccurrence identified research gaps and trends to be followed up with further study. The learnings of the present study revealed potential lines of future research among which the following can be mentioned:

- Exploring the gaps in research regarding the technological dimension related to entrepreneurship education. How can science parks build or develop competencies and incite entrepreneurial activity? What is their place in the educational ecosystem of the future? How can technology transfer be enhanced in order to fuel entrepreneurship?

- Exploring the potential of educational innovations in building up competencies. What are some challenges in doing this, and how is the Covid quarantine disrupting or boosting their integration?

The implications of this research findings are in no way negligeable. The academic world, as stated before, can use the data to further the study both in the same direction or in interdisciplinary areas. Higher education institutions may want, for management purposes, to use these same findings, while public institutions and government can initiate diverse, legitimate measurements such as the one on publicly funded research, its value and impact.

Since a bibliometric study is evaluating research by means of mathematics and statistics, identifying patterns and revealing gaps, the potential future theme-related research is based on these findings, while the limitations of the study suggest potential new lines of inquiry, new adjustments to be made to the present study (for example to the study's methodology) in order to clarify its angle or enlarge its outlook. Thus, one limitation of the study that has been identified is the focus put solely on the articles yielded by the search query. Out of the initial search results of 763 
records (including articles, proceedings papers, book chapters, reviews, etc.), the results' refinement reduced the number to 160 works, exclusively articles. The proceedings papers counted 348 records, which is two times a greater number than the collection analyzed herein. This means that relevant research has been a lot more in the focus of conferences than of journals' articles. Therefore, it is expected that future similar research endeavors could also integrate the proceedings, for a larger perspective.

This paper's contribution to the state of the art on entrepreneurial competencies and HEIs resides on the fact that the analysis shines a direct light on a narrow field of study that accommodates these two major research topics, evaluating its stamina and its future potential for more in-depth analysis.

Based on a comprehensive analysis, this paper's new findings can be of critical importance to assess emerging trends with valuable implications for future research in the under-explored field of entrepreneurial competencies and HEI.

\section{Acknowledgments}

This paper received financial support through the project "SmartDoct - High quality programs for doctoral students and postdoctoral researchers of the University of Oradea to increase the relevance of research and innovation in the context of regional economy", ID / Project code: 123008, co-financed by the European Social Fund through the Human Capital Operational Program 2014-2020.

\section{References}

- Badulescu, A. and Badulescu, D. (2013), 'How Entrepreneurial are Doctoral Students? Some Evidence from Romania', Journal of Eastern Europe Research in Business\&Economic, 2013(2013). DOI: 10.5171/2013.186798.

- Badulescu, A., Badulescu, D., Csintalan, C. and Simut, R. (2020), 'Teaching Entrepreneurship: How Prepared are
Romanian Educators?' Springer Proceedings in Business and Economics, ISBN: 978-3-030-43449-6_4 in: Fotea, S., Fotea, I. and Văduva, S. (ed.), Challenges and Opportunities to Develop Organizations Through Creativity, Technology and Ethics, Springer Proceedings in Business and Economics, 51-57.

- Baptista, R. and Naia, A. (2015), 'Entrepreneurship Education: A Selective Examination of the Literature', Foundations and Trends $\AA$ in Entrepreneurship, 11(5), 337-426. DOI: 10.1561/0300000047.

- $\quad$ Bilen, S.G., Kisenwether E.C., Rzasa S.E. and Wise J.C. (2005), 'Developing and assessing students' entrepreneurial skills and mind-set', Journal of Engineering Education, 92(2), 233-243. DOI: $\quad 10.1002 / \mathrm{j} .2168$ 9830.2005.tb00844.x.

- Bird, B. (1995), 'Towards a theory of entrepreneurial competency', Advances in Entrepreneurship, Firm Emergence and Growth, 2(1), 51-72.

- CEDEFOP (European Centre for the Development of Vocational Training) (2005). Improving lifelong guidance policies and systems. Using common European reference tools. [Online]. Luxembourg: Office for Official Publications of the European Communities. [Retrieved January 22, 2021]. Available: https://www.cedefop.europa.eu/files/4 045 en.pdf

- Chandler, G. and Jansen, E. (1992), 'The founder's self-assessed competence and venture performance', Journal of Business Venturing, 7(3), 223-236. DOI: 10.1016/0883-9026(92)90028-P.

- Fatoki, 0.0. (2010), 'Graduate Entrepreneurial Intention in South Africa: Motivations and Obstacles', International Journal of Business and Management, 5(9), 87-98. DOI: 10.5539/ijbm.v5n9p87.

- Ferreras-Garcia, R., Hernández-Lara, A. and Serradell-López, E. (2019), 'Entrepreneurial competences in a higher education business plan course', Education + Training, 61(7/8), 850-869. DOI: $10.1108 /$ ET-04-2018-0090. 
- Fetscherin, M. and Heinrich, D. (2015), 'Consumer brand relationships research: a bibliometric citation meta-analysis', Journal of Business Research, 68 (2), 380390.

DOI: 10.1016/j.jbusres.2014.06.010.

- Garfield, E., Paris, S.W., Stock and W.G. (2006), 'A Software Tool for Informetric Analysis of Citations Linkage', Information, 57(8), 391-400.

- Kakkonen, M. (2011), 'Students' perceptions of their business competences and entrepreneurial intention', Management, 6(3), 225-243.

- Kleinberg, J. (1999), 'Authoritative sources in a hyperlinked environment', Journal of the ACM, 46, 604-632. DOI: 10.1145/324133.324140.

- Loué, C., Laviolette, E.M. and BonnafousBoucher, M. (2008), 'L'entrepreneur à l'épreuve de ses compétences: éléments de construction d'un référentiel en situation d'incubation', Revue de l'Entrepreneuriat, 7(1), 63-83.

- Man, T., Lau, T. and Chan, K. (2002), "The competitiveness of small and medium enterprises: a conceptualization with focus on entrepreneurial competencies', Journal of Business Venturing, 17(2), 123142.

- Maresch, D., Harms, R., Kailer, N. and Wimmer-Wurm, B. (2016), 'The impact of entrepreneurship education on the entrepreneurial intention of students in science and engineering versus business studies university programs', Technological Forecasting and Social Change, 104, 172-179. DOI: 10.1016/j.techfore.2015.11.006.

- Matlay, H. (2008), 'The impact of entrepreneurship education on entrepreneurial outcomes', Journal of Small Business and Enterprise Development, 15(2), 382-396. DOI: $10.1108 / 14626000810871745$.

- Mitchelmore, S. and Rowley, J. (2010), 'Entrepreneurial competencies: a literature review and development agenda', International Journal of Entrepreneurial Behavior and Research, 16(2), 92-111. DOI: $10.1108 / 13552551011026995$.

- Politis, D. (2005), 'The process of entrepreneurial learning: a conceptual framework', Entrepreneurship Theory and Practice, 29(4), 399-424. DOI: 10.1111/j.1540-6520.2005.00091.x.

- Sánchez, J. (2011), 'University training for entrepreneurial competencies: its impact on intention of venture creation', International Entrepreneurship Management Journal, 7(2), 239-254. DOI: $10.1007 / \mathrm{s} 11365-010-0156-x$.

- Shah, S.H.H, Shen, L., Ali, M., Dorodin, D. and Hussain, S.T. (2019) 'Prosumption: bibliometric analysis using HistCite and VOSviewer', Kybernetes ahed-of-print. DOI: 10.118/K-12-2018-0696.

- Smith, A., Bradshaw, T., Burnett, K., Docherty, D., PurcelL, W. and Worthington, S. (2010). One Step Beyond: Making the most of postgraduate education. [Online]. [Retrieved March 6, 2021]. Available: https://dera.ioe.ac.uk/470/7/10-704one-step-beyond-postgraduateeducation_Redacted.pdf

- Thelwall, M. (2008), 'Bibliometrics to webometrics', Journal of Information Science, 34 (4), 605-621. DOI: $10.1177 / 0165551507087238$.

- Tittel, A. and Terzidis, O. (2020), 'Entrepreneurial competences revised: developing a consolidated and categorized list of entrepreneurial competences', Entrepreneurship Education, 3:1-35. DOI: 10.1007/s41959-019-00021-4

- Waltman, L., Noyons, E. (2018), 'Bibliometrics for Research Management and Research Evaluation', Leiden University, Centre for Science and Technology Studies, Leiden. 